\author{
Research Article \\ www.ijrap.net (ISSN:2229-3566)
}

\title{
A CROSS-SECTIONAL STUDY ON THANDAGAVATHAM (LUMBAR SPONDYLOSIS) TO ASSESS THE LIFESTYLE FACTORS IN PATIENTS
}

K. Mahalakshmi ${ }^{1}$, H Vetha Merlin Kumari ${ }^{2 *}$, H.Nalini Sofia ${ }^{2}$, T. Lakshmi Kantham ${ }^{3}$, R. Meena Kumari ${ }^{4}$

${ }^{1}$ PG scholar, Department of Maruthuvam, National of Institute of Siddha, Tambaram Sanatorium, Chennai, Tamil Nadu, India

${ }^{2}$ Associate Professor, Department of Maruthuvam, National of Institute of Siddha, Tambaram Sanatorium, Chennai, Tamil Nadu, India

${ }^{3}$ Associate Professor, Head of the Department (i/c), Department of Maruthuvam, National of Institute of Siddha, Tambaram Sanatorium, Chennai, Tamil Nadu, India

${ }^{4}$ Director, Head of the Department, Department of Gunapadam, National of Institute of Siddha, Tambaram Sanatorium, Chennai, Tamil Nadu, India

Received on: 18/07/21 Accepted on: 18/09/21

\author{
*Corresponding author \\ E-mail: dr.vetha@gmail.com
}

DOI: $10.7897 / 2277-4343.1205139$

\begin{abstract}
:
Lumbar Spondylosis in earlier days used to be an ailment of people in their 60 s and above. In recent years this trend is changing. Many lifestyle factors are blamed for this transition. Yet the factors are different for each population. In National Institute of Siddha Hospital, Lumbar spondylosis is one of the most common ailments for which patient visits OPD. Hence, A cross-sectional study was carried out to get an idea about which of those factors were common in the Thandagavatham patients visiting this hospital. Aim: To establish the most common lifestyle factors in Thandagavatham patients reporting at Ayothidoss Pandithar hospital OPD, National Institute of Siddha. Materials and methods: All the patients with a known history of Thandagavatham (Lumbar Spondylosis) were screened for this study. After obtaining informed consent, about 200 people were questioned to know about their lifestyle. Data was collected using the pre-designed questionnaire. The frequency for each factor was obtained after feeding the data in MS excel software. Result: Out of 14 factors considered in the study, age, menopause, BMI, socioeconomic status, exercise, history of falls were common among the study population.
\end{abstract}

Keywords: Thandagavatham, Siddha, Lumbar Spondylosis, lifestyle factors, cross-sectional study

\section{INTRODUCTION}

Siddha system of medicine is one of the traditional systems of medicine existing in the southern part of India ${ }^{1}$, Tamil Nadu from times immemorial. This system of medicine is established by a group of people called siddhars ${ }^{2}$ based on 3 vital humours namely Vatha, Pitha, and Kabha. It is believed that diseases in human often results as the by-product of these humour derangements. According to Siddhar Yugi, there are nearly 80 kinds of Vatha diseases ${ }^{3}$.

Thandagavatham (Lumbar Spondylosis) is one among them. Lumbar Spondylosis in earlier days used to be an ailment of people in their $60 \mathrm{~s}$ and above. In recent years this trend is changing. About 266 million people around the world are suffering from Lumbar degenerative disorders. Of these, Lumbar spondylosis happens to be one of the most common orthopaedic ailments for which patients tend to visit the hospital frequently especially in Nigeria ${ }^{4}$.

In the United States, about $80 \%$ of individuals above 40 years have lumbar spondylosis ${ }^{5}$. Similar patterns are seen in India as well. Several factors like age, menopause ${ }^{6}, \mathrm{BMI}^{7}$, smoking ${ }^{8,9}$ etc. are blamed for this transition. Though, the prevalence of each factor among people varies. So, a cross-sectional study was carried out to see the distribution of these factors in our setting.

\section{MATERIALS AND METHODS}

This study was carried out after obtaining IEC (Institutional Ethics Committee) approval - NIS/IEC/2020/MP-4 and registering in CTRI - (Clinical trial registry of India)CTRI/2020/08/027141.

All the Thandagavatham (Lumbar spondylosis) patients who reported at OPD no.1 of the National Institute of Siddha were screened for this study. Patients were then selected using the NonRandomised (judgmental) sampling method. After obtaining written consent, the sample population were interviewed using the Pre-designed questionnaire for data regarding their lifestyle and economic status.

Blood samples were then collected from each patient to document their Serum Calcium ${ }^{10}$ and Protein levels. Individual data were fed simultaneously into an MS excel sheet. After obtaining data from the required sample size (200 patients), the frequency for each factor was obtained. 


\section{OBSERVATION AND RESULTS}

Table 1: Factors that were common among the Thandagavatham patients

\begin{tabular}{|c|c|c|}
\hline Factor & Predominant Category & Percentage \\
\hline Age & $40-50$ years & 65.5 \\
\hline Sex Distribution & Female $(108)$ & 54 \\
\hline Smoking & Men (92) & 51.3 \\
\hline Menopause History & Attained & 50 \\
\hline BMI & $18.5-24.9 \mathrm{~kg} / \mathrm{m}^{2}$ & 46.5 \\
\hline Socioeconomic Status & $25-29.9 \mathrm{~kg} / \mathrm{m}^{2}$ & 24.5 \\
& Upper Lower & 28 \\
\hline Lower Middle & 21.5 \\
\hline Food & Upper Middle & 75.5 \\
\hline Beverage & Non-Veg & 60.5 \\
\hline Ext Drink & Tea & 30.5 \\
\hline TV & Yes & 64.5 \\
\hline Posture at Work & Yes & 41 \\
\hline History of Fall & $1-2$ hours/day & 52 \\
\hline
\end{tabular}

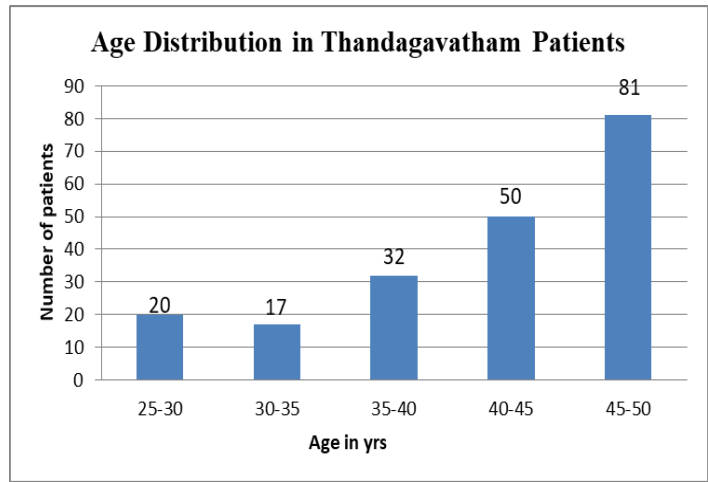

Graph 1: Age distribution in Thandagavatham patients

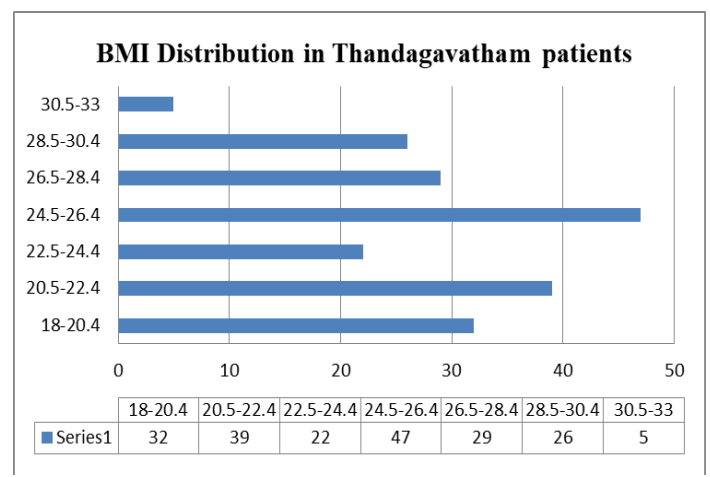

Graph 3: BMI distribution in Thandagavatham patients

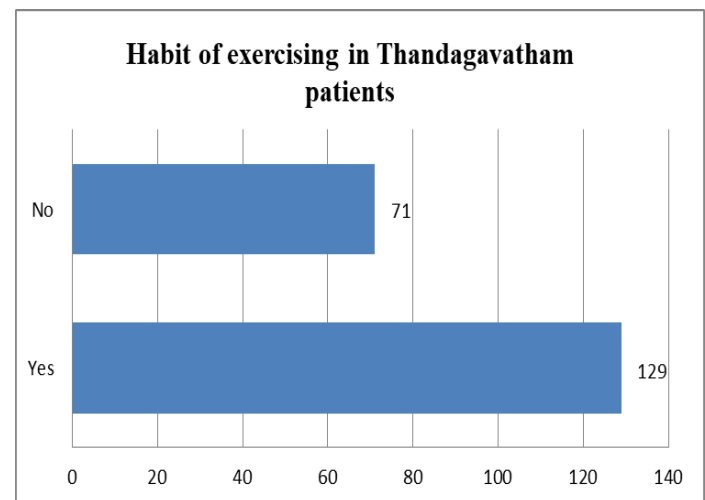

Graph 5: Habit of exercising in Thandagavatham patients

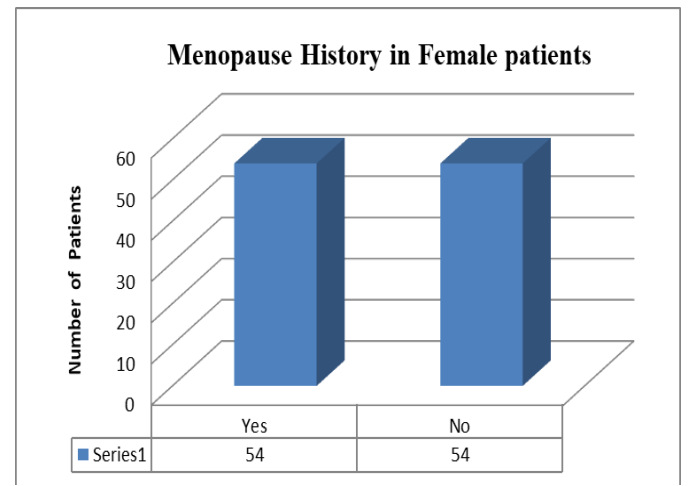

Graph 2: Menopause history in Female patients

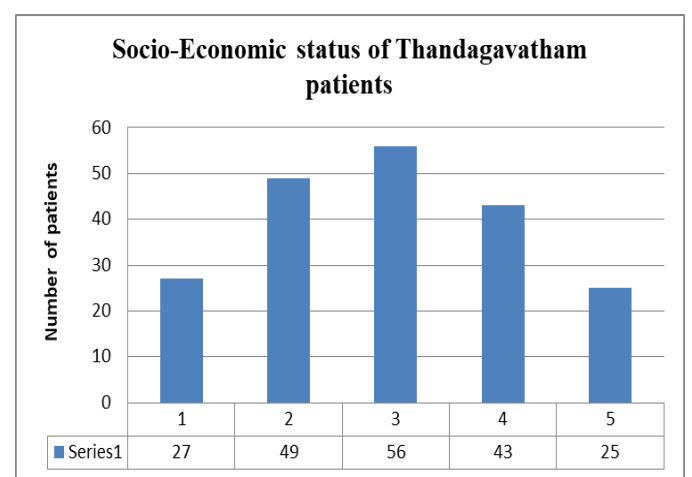

Graph 4: Socio-economic status of Thandagavatham patients

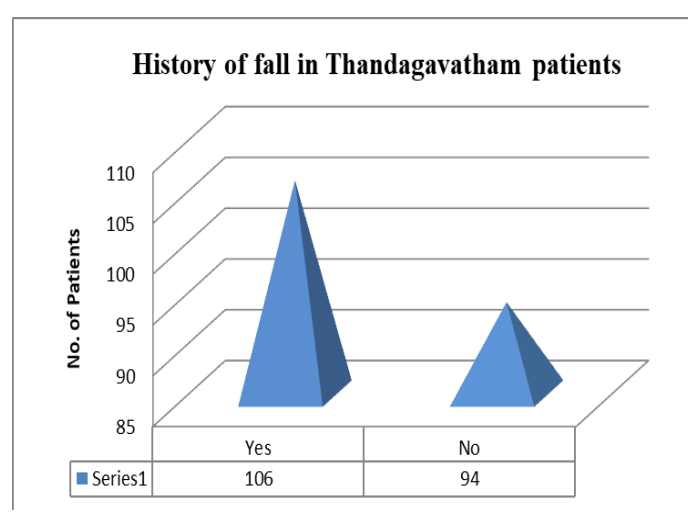

Graph 6: History of fall in Thandagavatham patients 


\section{DISCUSSION}

Lifestyle factors like Age, sex, socio-economic status, posture etc. were observed in this study. The frequency of each factor was observed in every patient to know how common those factors are in the life of these patients. Observations are discussed below.

Age is an important factor in the development of lumbar spondylosis. As age progresses, the rate of degeneration in the discs increases. In this study, most of the people belonged to the age group of 45 to 50 years (Graph 1), supporting the fact.

Although the sex ratio is said to be of equal proportion ${ }^{5}$ in the general population, in this study out of 200 people, $54 \%$ is female making the female sex predominant in this study. This may be due to the socio-economic status which imposes extra workload in addition to their home chores.

Smoking ${ }^{8,9}$ is described as a significant risk factor in several studies. Yet, out of 92 men in the study, $41.3 \%$ of men had a smoking habit or history.

Menopause $^{6}$ accelerates the degeneration process in the vertebral discs. This is due to the oestrogen deficiency in those women. Likewise, $50 \%$ of women in this study (Graph 2) had attained menopause.

Higher $\mathrm{BMI}^{7}$ affects the health of the lumbar discs by putting extra load on the spine. In this study, $46.5 \%$ of people were overweight, $2 \%$ of the population were obese (Graph 3 ).

The economic status of a man determines one's physical and mental health. Most of the people in the sample population were in the Upper Lower, Lower Middle and Upper Middle socioeconomic status (Graph 4) making them vulnerable to physical stress and mental stress.

Food habits $75.5 \%$ of people belonged to the non-vegetarian group. The remaining $23 \%$ and $1.5 \%$ of people were vegetarian and eggetarian respectively. Among non-vegetarians, the chicken was the main diet taken by $55.62 \%$ of people. Most nonvegetarians said that they have non-veg weekly once or twice.

A study ${ }^{11}$ reported that caffeine intake increased bone loss. However, out of the 3 common beverages, Tea was the most common beverage taken by $60.5 \%$ of people, which contains less amount of caffeine. Hence it was not an important factor.

A Systemic review ${ }^{12}$ stated that replacing milk with soft drinks results in Osteoporosis and back pain. Hence people were asked about their interest in consuming soft drinks. About, 30.5\% of people in this study had the habit of taking soft drinks, with the frequency of intake weekly once which makes it less likely agent.

$64.5 \%$ of people (Graph 5) in the population exercise. Among them walking was the most common exercise in $56.5 \%$ of the population who exercise. Most people 52\% work out for up to 1 hour per day. Prolonged static sitting increases the load to the spine $^{13}$.

$41 \%$ of people in this study spent about 1 to 2 hours watching TV. $37.5 \%$ of people were either professionals or with desk jobs forced to be in the sitting posture for most of the day. Among them, $68 \%$ of people said that they maintain erect sitting posture during their working hours. $10.5 \%$ of people spent most of their time standing. Among them, $62 \%$ of people stood for more than 5 hours per day. A study stated that driving more than 4hours/day ${ }^{14}$ was a risk factor for developing the disease.
In this study, $21.5 \%$ of people said that they travel often. The bike was the most common mode of transport among these people travelling up to 1 hour per day. $53 \%$ of people had a history of falls (Graph 6) to their spine. $80 \%$ of the people said that they have been suffering from this condition for the past 5 years. Most of the people in the study population have a pain scale between 3 to 6 .

Most of the people in the study population, had the calcium concentration between 8 to $9 \mathrm{mg} / \mathrm{dl}$, their total protein concentration within the range of 7 to 8 grams/dl and Albumin and globulin in the range 3.5 to $4.4 \mathrm{~g} / \mathrm{dl}$ and 2.5 to $3.4 \mathrm{~g} / \mathrm{dl}$ respectively.

\section{CONCLUSION}

Out of 14 factors considered in the study, age, menopause, BMI, socioeconomic status, exercise, history of fall was common among the population. Ageing is an inevitable phenomenon that everyone experiences. Although ageing is inevitable, the degenerative changes which occur in our discs can be managed by adding antioxidant-rich foods to our diet. Menopause affects the bone health of women. Sufficient intake of Vitamin D and calcium along with adequate sunlight exposure will help a woman to cope with changes associated with it. Excess weight puts extra load on the vertebral column and discs. Healthy weight loss might reduce the load to the spine and so prevent further degeneration in the discs. Proper education about the disease can be provided to people of low socioeconomic status to make themselves aware of the potential risks at their work and prevent them from injuring themselves. Although most people exercise, those who, do exercise especially involving weight lifting tend to develop disc bulges and desiccation. So, an exercise involving weights should be done under a trained professional's guidance. The history of falls was a very important factor in the development of the disease, especially among people in their mid-30s. Most of them had a history of falls while driving. So, safe driving might reduce the chances of falls and the condition. Hence, minor changes to their lifestyle might help people to avoid further degeneration and prevent the development of disease in others.

\section{REFERENCES}

1. P. Sharmila et al. Standardization of a Siddha Herbomineral Formulation: Karasooda Sathu Parpam. Int. J. Res. Ayurveda Pharm [serial on the Internet]. 2020 Nov [cited on 2021 Mar 3]; 11(5): [103-105].Available from: https://www. researchgate.net/publication/345943480_Standardization_of _a_siddha_herbomineral_formulation_karasooda_sathu_par pam

2. Nivetha $T$ et al. Standardization of a Siddha herbomineral formulation: Kandaamalaga Ilakam. Int. J. Res. Ayurveda Pharm [serial on the Internet]. 2020 Jan [cited on 2021 Mar 3]; 11(1): [83-85].Available from: https://www.researchgate. net/publication/338777398_Standardization_of_a_siddha_he rbomineral_formulation_kandaamalaga ilakam

3. Kuppuswamy mudhaliar. Siddha Maruthuvam (Pothu).8th ed. Chennai: Directorate of Indian medicine and Homeopathy; (2016)

4. Edomwonyi EO, Ogbue IA. Epidemiology of low back pain in a suburban Nigerian tertiary centre. Niger J SurgSci [serial online] 2017[cited 2020 Mar 14]; 27:20-5. Available from: http://www.njssjournal.org/text.asp?2017/27/1/20/230692

5. emedicine.medscape.com [homepage on the Internet].New York: Lumbar Spondylosis; [updated on 2018 Sep 25; cited on 2020 Mar 14].Available from: https://emedicine. medscape.com/article/249036-overview

6. Yi Xiang J. Wang. Postmenopausal Chinese women show accelerated lumbar disc degeneration compared with Chinese men. J Orthop Translat [serial on the Internet]. 2015 Sep 
[cited on 2020 Mar 20]; 3(4): [205-207]. Available from: https://pubmed.ncbi.nlm.nih.gov/30035059/

7. Dino Samartzis, Jaro Karppinen, Danny Chan, Keith D K Luk, Kenneth MC Cheung, The association of lumbar intervertebral disc degeneration on magnetic resonance imaging with body mass index in overweight and obese adults: a population-based study. Arthritis \& Rheumatism [serial on the Internet].2012 May [cited on 2020 Mar 20]; 64(5): [1488-91].Available from: https://pubmed.ncbi.nlm. nih.gov/22287295/

8. Oichi T, Taniguchi Y, Oshima Y, Tanaka S, Saito T. Pathomechanism of intervertebral disc degeneration. JOR Spine [serial on the Internet]. $2020 \mathrm{Feb}$ [cited on $2020 \mathrm{Mar}$ 20]; 3(1):e1076. Available from: https://www.ncbi.nlm.nih. gov/pmc/articles/PMC7084053/

9. Ande M. Jakoi, Gurpal Pannu, Anthony D'Oro1, et al. The Clinical Correlation Between Diabetes, Cigarette Smoking and Obesity on Intervertebral Degenerative Disc Disease of the Lumbar Spine. Asian Spine Journal [serial on the Internet]. 2017 Jun [cited on 2020 Mar 21]; 11(3): [337-339]. Available from: https://www.ncbi.nlm.nih.gov/pmc/ articles/PMC5481588/

10. Zhao, B., Wang, K., Zhao, J. et al. Serum Calcium Concentration as an Indicator of Intervertebral Disk Degeneration Prognosis. Biol Trace Elem Res [serial on the Internet]. 2013 July [cited on 2020 Mar 28]; 154(3): [333335]. Available from: https://pubmed.ncbi.nlm.nih.gov/ 23892694/

11. Prema B Rapuri, J Christopher Gallagher, H Karimi Kinyamu, Kay L Ryschon. Caffeine intake increases the rate of bone loss in elderly women and interacts with vitamin D receptor genotypes. Am J Clin Nutr [serial on the Internet].
2001 Nov [cited on 2020 Mar 28]; 74(5): [694-696]. Available from: https://pubmed.ncbi.nlm.nih.gov/11684540/

12. Mohamed.M. Gamaleldin et al.Use of soft drinks and risk of Osteoporosis: a systemic review.Int.Res.J.Pharm [serial on the Internet]. 2018 Sep [cited on 2020 Mar 28]; 9(10). Available from: https://www.researchgate.net/publication/ 329375531 Use of soft drinks and risk of osteoporosis a_systematic_review.

13. Makhsous M, Lin F, Bankard J, Hendrix RW, Hepler M, Press J. Biomechanical effects of sitting with adjustable ischial and lumbar support on occupational low back pain: evaluation of sitting load and back muscle activity. BMC Musculoskelet Disord [serial on the Internet]. 2009 Feb [cited on 2020 Mar 28]; 10:17.Available from: https://www. ncbi.nlm.nih.gov/pmc/articles/PMC2654542/

14. Samal, Nitin \& Deshpande, Romil et al. Analysis of Incidence of Lumbar Spondylosis by Gender in Rural Area its Severity \& Occupational Consequences: Rare Indian Study. The Journal of Maharashtra Orthopaedic Association [serial on the Internet]. 2013 Jan [cited on 2020 Mar 29]; 8(4): [22-26]. Available from: https://www.researchgate.net/publication/ 305800355_Analysis_of_Incidence_of_Lumbar_Spondylosi $\mathrm{s}$ by Gender in Rural Area its Severity Occupational C onsequences_Rare_Indian_Study

\section{Cite this article as:}

K. Mahalakshmi et al. A cross-sectional study on Thandagavatham (lumbar spondylosis) to assess the lifestyle factors in patients. Int. J. Res. Ayurveda Pharm. 2021;12(5):38$41 \mathrm{http} / / / \mathrm{dx}$. doi.org/10.7897/2277-4343.1205139

Disclaimer: IJRAP is solely owned by Moksha Publishing House - A non-profit publishing house, dedicated to publishing quality research, while every effort has been taken to verify the accuracy of the content published in our Journal. IJRAP cannot accept any responsibility or liability for the site content and articles published. The views expressed in articles by our contributing authors are not necessarily those of IJRAP editor or editorial board members. 